\title{
Pengaruh Promosi Cashback pada OVO dan Go-Pay Terhadap Perilaku Konsumen Mahasiswa Fakultas Ekonomi dan Bisnis Universitas Padjadjaran
}

\author{
Risya Nurrohyani $^{1^{*}}$, Estro Dariatno Sihaloho ${ }^{2}$ \\ ${ }^{1,2}$ Fakultas Ekonomi dan Bisnis Universitas Padjadjaran \\ Jl. Raya Bandung Sumedang KM.21, Hegarmanah, Kec. Jatinangor, Kabupaten Sumedang \\ *e-mail : risya17002@mail.unpad.ac.id
}

\author{
Artikel Info \\ Received : \\ 22 November 2019 \\ Revised : \\ 09 Desember 2019 \\ Accepted : \\ 15 Mei 2020
}

\begin{abstract}
ABSTRAK
Dalam beberapa tahun ini, pengguna financial technology (fintech) meningkat signifikan di Indonesia karena penggunaan aplikasi yang mudah dan cepat. Financial technology (fintech)yang paling banyak digunakan di Indonesia yaitu OVO dan Go-Pay. OVO dan Go-Pay merupakan aplikasi transaksi non-tunai. Kemudahan penggunaan dan promosi-promosi yang dilakukan OVO dan GoPay menjadi daya tarik bagi konsumen. Salah satu promosi yang sering dilakukan adalah cashback. Cashback merupakan pengembalian dana dari pembelian produk atau pembayaran jasa dengan menggunakan OVO dan Go-Pay. Penelitian ini bertujuan untuk mengalisis pengaruh cashback OVO dan Go-Pay terhadap perilaku konsumsi mahasiswa Fakultas Ekonomi dan Bisnis Universitas Padjadjaran. Variabel independen yang digunakan adalah variabel pendapatan $\left(\mathrm{X}_{1}\right)$, total penggunaan OVO dan GoPay $\left(\mathrm{X}_{2}\right)$, serta cashback $\left(\mathrm{X}_{3}\right)$. Penelitian ini menggunakan data sampel sebanyak 83 mahasiswa Fakultas Ekonomi dan Bisnis Universitas Padjadjaran. Hasil penelitian ini menunjukan pendapatan serta penggunaan OVO dan Go-Pay berpengaruh positif dan signifikan terhadap pengeluaran mahasiswa, sedangkan cashback berpengaruh secara negatif dan signifikan terhadap pengeluaran mahasiswa.
\end{abstract}

Kata kunci : Financial technology, OVO, Go-Pay, Cashback.

\section{The Effect of Cashback Promotion on OVO and Go-Pay Against Consumer Behavior of Padjadjaran University Faculty of Economics and Business Students}

\begin{abstract}
In recent years, users of financial technology (fintech) have increased significantly in Indonesia due to the use of applications that are easy and fast. The most widely used financial technology (fintech) in Indonesia is OVO and Go-Pay. OVO and Go-Pay are non-cash transaction applications. The ease of use and promotions by OVO and Go-Pay are attractive for consumers. One of the promotions that are often done is cashback. Cashback is a refund
\end{abstract}


from product purchases or service payments using OVO and GoPay. This study aims to analyze the effect of OVO and Go-Pay cashback on student's consumption behavior of Faculty of Economics and Business in Padjadjaran University. The independent variables used are income $\left(X_{-} 1\right)$, total using of $O V O$ and Go-Pay (X_2), and cashback (X_3). This study used a sample of 83 students from the Faculty of Economics and Business, Padjadjaran University. The results of this study indicate income and use of $\mathrm{OVO}$ and Go-Pay have a positive and significant effect on student spending, while the cashback has a negative and significant effect on student spending.

Keywords : Financial technology, OVO, Go-Pay, Cashback.

\section{PENDAHULUAN}

Perkembangan teknologi yang semakin canggih dan terbaru memberikan banyak manfaat, seperti fitur yang memudahkan pekerjaan manusia yaitu financial technology. Financial technology atau dikenal dengan sebutan fintech merupakan penggantian uang tunai menjadi non-tunai dengan menggunakan aplikasi. Menurut Peraturan Bank Indonesia Nomor 19/12/PBI/2017 dalam (Rahma, 2018) financial technology merupakan adanya pemanfaatan teknologi dalam hal keuangan yang dapat menghasilkan suatu produk dan bisa memberikan pelayanan dalam melakukan pembayaran. Pada tahun 2017, pengguna internet di Indonesia mencapai 143,26 juta jiwa dari jumlah penduduk 262 juta orang. Adanya peningkatan penggunaan internet oleh penduduk Indonesia menjadi salah satu alasan diciptakannya financial technology (fintech) yang bertujuan untuk memudahkan dalam pembayaran dan transaksi dalam hal apapun. Layanan fintech bisa digunakan ketika sudah tersambung dengan internet yang di akses melalui smartphone, sehingga penggunaannya menjadi mudah dan cepat. Dengan adanya fintech di Indonesia bisa bermanfaat sebagai : pemerataan kesejahteraan penduduk, pembiayaan dalam negeri, distribusi pembiayaan nasional, pendorong kemampuan ekspor UMKM, dan untuk meningkatkan inklusi keuangan (Suharyati \& Sofyan, 2018).

Di Indonesia sudah mulai dikenal adanya financial technology (fintech)dalam kurun beberapa tahun terakhir, salah satunya yaitu OVO dan Go-Pay. OVO merupakan aplikasi layanan transaksi secara online yang berasal dari perusahaan Lippo, penggunaan OVO terdiri dari dua macam, yaitu OVO Cash yang digunakan untuk pembayaran-pembayaran di menchant-menchant yang telah bekerjasama dengan OVO. Yang kedua yaitu OVO Point merupakan hadiah yang diberikan karena telah melakukan pembayaran dengan menggunakan OVO Cash. OVO Point dapat ditukarkan dengan berbagai transaksi yang ditawarkan oleh menchant yang telah bekerja sama dengan OVO. Penggunaannya OVO sering dikenal sebagai pembayaran Grab yang digunakan untuk membayar delivery makanan ataupun GrabBike dan GrabCar.

Sedangkan Go-Pay merupakan uang elektronik yang digunakan untuk melakukan transaksi di aplikasi Go-Jek.Go-Pay ini bisa digunakan untuk membayar delivery makanan atau yang dikenal dengan Go-Food, Go-Bills yang digunakan untuk membayar PLN, BPJS, Voucher Google Play, PDAM, Games Voucher, TV kabel \& Internet, Gas PGN, dan lainnya, bisa juga digunakan untuk pembayaran Go-Ride, Go-Car, dan Go-Bluebird yang merupakan kendaraan yang bisa digunakan untuk mengatar kesemua tempat, Go-Tix yang digunakan untuk pembelian tiket nonton bioskop, Go-Life yang terdiri dari Go-Massage,

Copyright@ 2020 , Ekonomikawan : Jurnal IImu ekonomi dan Studi Pembangunan. This is an open access article under the 
Go-Clean, Go-Auto, dan Go-Glam merupakan penyedia jasa layanan profesional dalam membantu pekerjaan. Selain itu, Go-Pay bisa digunakan untuk Go-Send yang merupakan jasa pengiriman barang, Go-Deals yang digunakan untuk membeli voucher-voucher, GoShop, Go-Pulsa, Go-Med, Go-Fix, Go-Auto, Go-Box, dan fitur lainnya.

Adanya kemudahan dalam pengisian saldo atau top-up yang bisa dilakukan di Bank, gerai Alfamart dan Indomart atau dengan pulsa, menjadikan fintech marak digunakan oleh masyarakat Indonesia terutama di kalangan muda. Sudah banyak perusahaan-perusahaan yang mengeluarkan fintech yang dapat membantu masalah transaksi pembayaran, contohnya DANA atau Dompet Digital Indonesia yang merupakan aplikasi pembayaran non-kartu dan non-tunai yang digunakan untuk membeli pulsa dan paket data, pembayaran Tix Id, voucher games, hingga pembayaran BPJS dan PLN. Sehingga muncul persaingan diantara perusahaan-perusahaan fintech untuk menjadi fitur fintech yang terbaik dan banyak digunakan masyarakat, hal tersebut membuat perusahaan melakukan iklan dan berbagai promosi-promosiyang bisa menguntungkan penggunanya.

Promosi yang sering digunakan oleh pengguna OVO dan Go-Pay yaitu vouchervoucher, Buy one Get one, Cashback, dan promosi lainnya. Promosi tersebut sering ditampilkan melalui iklan-iklan dengan kata -kata yang menarik penggunanya, tidak jarang konsumen akan mudah tergoda dan akan mempercepat untuk mengkonsumsi produk tersebut. Hal tersebut sesuai dengan penelitian sebelumnya yang menyatakan bahwa pemberian promosi penjualan kepada konsumen akan mempengaruhi terhadap keputusan pembelian (Khairunissa, Suharyono, \& Yulianto, 2017). Salah satu promosi yang sering digunakan oleh konsumen, yaitu adanya pemberian cashback. Cashback merupakan pengembalian dana atau uang yang digunakan dalam pembayaran, biasanya cashback sering dilakukan oleh OVO dan Go-Pay untuk menarik para pengguna fintech. Pemberian cashback ini bisa mencapai 20\%,30\% bahkan bisa mencapai 50\%. Pemberian cashback tidak diberikan secara percuma, tetapi berdasarkan persyaratan-persyaratan yang diajukan oleh perusahaan tersebut, seperti adanya minimal pembelanjaan untuk bisa menggunakan promosi cashback.

Informasi yang dideskripsikan pada penelitian ini meliputi penggunaan OVO dan Go-Pay oleh mahasiswa yang berpengaruh terhadap pengeluaran dan besaran cashback yang ditetapkan oleh OVO dan Go-Pay. Diharapkan dengan adanya penelitian ini mahasiswa ataupun pihak terkait bisa mendapatkan informasi berupa data tentang adanya promosi cashback OVO dan Go-Pay yang berpengaruh terhadap perilaku konsumen untuk penelitian selanjutnya dan bisa digunakan untuk kebutuhan lainnya.

\section{KAJIAN TEORI \\ Perilaku Konsumen}

Menurut Keynes, seseorang akan menambah konsumsinya ketika adanya penambahan pendapatan dan ketika masih ada sisa pendapatan akan disimpan sebagai tabungan (Mankiw, 2009). Sedangkan menurut Irving Fisher, seseorang akan mendapatkan kepuasan yang tinggi ketika konsumen tersebut memikirkan bagaimana untuk mengonsumsi saat ini dan dimasa yang akan datang (Mankiw, 2009). Berdasarkan hasil penelitian, adanya status sosial ekonomi orang tua, literasi ekonomi, dan life style berpengaruh terhadap perilaku konsumsi (Astuti, 2016). Perilaku konsumsi bisa dilihat dengan tindakan yang akan dilakukan oleh konsumen, seperti mahasiswa. Keinginan untuk berbelanja dan memenuhi kebutuhan yang harus terpenuhi merupakan sesuatu yang bisa dilihat dari perilaku konsumsi mahasiswa, mahasiswa perempuan akan mudah tergoda dengan adanya iklan dan pengaruh teman-temannya sehingga menjadi boros, sedangkan 
mahasiswa laki-laki akan lebih mudah terpengaruh dengan budaya konsumerisme (Lisma \& Haryono, 2016).

\section{Technology Acceptance Model (TAM)}

Technology Acceptance Model (TAM) merupakan sebuah model untuk melihat bagaimana penerimaan dari pengguna dengan adanya teknologi dengan melihat presepsi kemudahan dalam penggunaan dan presepsi manfaat (Davis, 1989). Model ini pertama kali dikenalkan oleh Fred D. Davis pada tahun 1989 yang merupakan penyempurnaan dari Theory Reasoned Action (TRA) yang dicetuskan oleh Fishbein dan Ajzen pada tahun 1975. Sudah banyak peneliti yang memperluas model Technology Acceptance Model (TAM) ini dengan menambahkan variable-variabel lainnya yang berpengaruh terhadap model tersebut. Menurut Pavlou (2003) dalam (Maghfira, 2018), untuk penggunaan teknologi tidak hanya ada pengaruh dari manfaat dan kemudahaan dalam penggunaan, tetapi adanya kepercayaan terhadap teknologi bisa mempengaruhi penggunaannya. Berdasarkan hasil penelitian Lee dan Wan (2010) dalam (Fitra, n.d.) adanya kemudahan dalam penggunaan teknologi karena dapat dipelajari dengan mudah, mudah dioperasikan, dan mudah diterapkan.

\section{Financial Technology}

Financial technology (fintech) merupakan sebuah layanan yang memanfaatkan teknologi informasi untuk menyediakan produk-produk keuangan (Ansori, 2019). Menurut Fintechnews.sg (2016) dalam (Wulan, 2017), para pengusaha yang menggunakan fintech biasa disebut dengan Start-Up, penggunaan fintech didasarkan karena besarnya pengguna internet yang mencapai 104,2 juta pada tahun 2016 dan akan di perkirakan pada tahun 2021 mencapai 144,2 penggunaan internet tersebut untuk mengakses social media, mengirim pesan, atau mendengarkan musik. Sedangkan menurut Philipon (2017) dalam (Irawati, 2018), fintech merupakan sebuah inovasi bisnis yang menggunakan teknologi dibidang keuangan dan merupakan inovasi digital dalam industri. Secara Global fintech mulai berkembang diberbagai sektor, seperti peminjamaan, star-up pembayaran, perencanaan keuangan, pembiayaan, remitasi, riset keuangan, dan lainnya (Muzdalifa, Rahma, \& Novalia, 2018). Salah satu cara untuk meningkatkan transaksi keuangan yaitu dengan financial technology (fintech), untuk itu perlu adanya peningkatan pengetahuan tentang layanan keuangan yang kekinian (Suharyati \& Sofyan, 2018).

\section{Promosi Cashback}

Cashback merupakan salah satu sales promotion. Menurut Kotler dan Armstrong (2011) dalam (Muiz, Rachma, \& Slamet, n.d.) sales promotion bertujuan untuk mendorong adanya penjualan dan pembelian suatu produk dalam jangka pendek. Pemberian promosi bertujuan untuk mengajak para konsumen untuk bisa menggunakan barang dan jasa, promosi mencakup iklan, promosi penjualan, penjualan personal, hubungan masyarakat, dan pemasaran secara langsung (Dianti, 2017). Dengan adanya promosi yang dilakukan akan berpengaruh terhadap emosi positif konsumen dan berpengaruh terhadap adanya pembelian implusit (Alfarizi, Rachma, \& Hufron, n.d.). Adanya promosi yang dilakukan Go-Jek melalui iklan ataupun dengan adanya potongan harga melalui Go-Pay berpengaruh terhadap kepuasan pelanggandan keputusan untuk menggunakan kembali aplikasi Go-Jek (Adriany, 2018). 


\section{METODE}

Penelitian ini menggunakan data primer yang diperoleh secara langsung dari mahasiswa Fakultas Ekonomi dan Bisnis, Universitas Padjadjaran dengan menggunakan 83 mahasiswa sebagai sampelnya. Adapun pengambilan data dilakukan dengan pengisian kuesioner. Kuesioner merupakan informasi yang diperoleh secara tertulis dengan sejumlah pertanyaan mengenai laporan pribadinya dan apa yang diketahui oleh responden (Aditya, 2013). Pengambilan data dimulai dari tanggal 29 April 2019 sampai dengan 09 Mei 2019 dengan ngambil sampel dari setiap jurusan yang ada di Fakultas Ekonomi dan Bisnis, Universitas Padjadjaran.

Metode yang digunakan dalam penelitian ini yaitu metode penelitian kuantitatif. Menurut Sugiano (2010) dalam (Hanifah, 2016), penelitian dengan menggunakan metode kuantitatif merupakan metode yang didasarkan terhadap filsafat positivism yang dapat digunakan untuk meneliti suatu sampel atau populasi dengan pengambilan sampel secara analisis dalam bentuk statistik yang dilakukan untuk pengujia hipotesis. Adapun teknik yang digunakan dalam penelitian ini yaitu purposive sampling dengan pengambilan sampel mahasiswa Fakultas Ekonomi dan Bisnis Universitas Padjadjaran yang merupakan pengguna OVO dan Go-Pay, sehingga sampel tidak bisa dipilih secara acak karena responden merupakan pengguna OVO dan Go-Pay untuk melihat dampak penggunaannya terhadap perilaku konsumen. Purposive sampling merupakan sampel yang diambil atas dasar kepentingan yang disesuaikan dengan penelitian menurut peneliti sehingga termasuk ke dalam kategori sampel yang harus diambil (Nasution, 2014).

Proses wawancara yang dilakukan dengan memberikan pertanyaan-pertanyaan yang terperinci kepada responden yang diharapkan akan bisa menjelaskan bagaimana pengaruh cashback terhadap perilaku konsumen. Adapun informasi yang diperoleh yaitu pengunaan OVO dan Go-Pay sesudah adanya cashback, kisaran cashback yang digunakan oleh responden, dan bagaimana pendapatan dan pengeluaran dari responden itu sendiri. Data yang diberikan oleh responden kemudian dianalisis dan diolah sehingga bisa mendapatkan kesimpulan dari adanya informasi-informasi yang telah diberikan oleh responden. Selain itu, data tersebut merupakan data yang asli didapatkan dari responden, meskipun ada hal yang masih kurang jelas akan ditanyakan lebih lanjut kepada responden.

Metode analisis regresi data yang digunakan yaitu OLS (Ordinary Least Square) dengan menggunakan variabel depanden dan variabel independen, dalam penelitian ini variabel yang digunakan dalam terdiri dari satu variabel dependen (Y) dan tiga variabel independent (X), yaitu:

Keterangan:

$$
\widehat{Y_{1}}=\widehat{\beta_{0}}+\beta_{1} \widehat{X_{11}}+\beta_{2} \widehat{X_{21}}+\beta_{3} \widehat{X_{31}}+\widehat{u_{1}}
$$

$\mathrm{Y}=$ Pengeluaran mahasiswa selama satu bulan

$\mathrm{X}_{1} \quad=$ Pendapatan atau uang saku mahasiswa selama satu bulan

$\mathrm{X}_{2} \quad$ = Kisaran cashback yang digunakan

$\mathrm{X}_{3}$ = Penggunaan OVO dan Go-Pay selama satu bulan

Penelitian ini menggunakan software STATA 15 yang membantu dalam menganalisis data-data. Adapun tahapan-tahapan dalam penelitian:

1. Uji Multikolonieritas

Multikolonieritas merupakan pengujian korelasi antar variable-variabel independen. Multikolonieritas terjadi ketika adanya hubungan linear yang sempurna dalam variable-variabel yang menjelaskan dari model regresi (Gujarati, 2003). Pengujian multikolonieritas bisa dengan menggunakan VIF (Variance Inflation Factor), dengan menggunakan nilai $R^{2}$, dan dengan menggunakan matrik korelasi. 


\section{Uji Heteroskedastisitas}

Heteroskedastisitas terjadi karena varians erornya yang tidak konstan, perubahan tersebut terjadi kerena adanya perubahan nilai variabel independennya. Kebalikan dari adanya Heteroskedastisitas yaitu Homosdesatisitas. Dalam analisi uji asumsi klasik adanya heteroskedastisitas dapat berpengaruh terhadap pengujian t, F-stat, dan Chisquare yang tidak valid, selain itu berpengaruh terhadap adanya kesimpulan regresi yang palsu. Untuk melihat adanya masalah heteroskedastisitas bisa dengan pengujian Breusch-Pagan (BP Test) atau dengan White Test. Penggunaan Breusch-Pagan (BP Test) ketika model analisis regresi linear, sedangkan White Test ketika model analisis regresinya non-linear.

3. Uji Hipotesis

- Uji F

Yaitu merupakan pengujian untuk melihat bagaimana pengaruhnya semua variabel independen yang ada dalam model regresi terhadap variabel dependen. Melihat adanya pengaruh dari variabel-variabel independen terhadap variabel dependen dari model ini dengan membandingkan nilai F-stat dan F-tabelnya. Apabila F-stat nilainya lebih besar dari F-tabel maka variabel-variabel indepenndenya berpengaruh terhadap model regresi.

- Uji t

Yaitu pengujian untuk melihat bagaimana signifikannya variabel independen terhadap variabel dependen. Dalam menganalisis melihat bagaimana pengaruh dari variabel independen yang ada dalam model regresi dengan melihat $t$-stat dibandingkan dengan t-tabelnya. Apabila t-statnya lebih besar dari t-tabel maka ada pengaruhnya dari variabel independen tersebut terhadap variabel dependen.

\section{HASIL DAN PEMBAHASAN}

Penelitian ini yang bertujuan untuk melihat adanya pengaruh promosi cashback pada OVO dan Go-Pay terhadap perilaku konsumen mahasiswa Fakultas Ekonomi dan Bisnis Universitas Padjadjaran, dengan mengasumsikan pendapatan, penggunaan OVO dan GoPay, serta kisaran cashback sebagai variabel yang mempengaruhi terhadap perilaku konsumen dengan melihat pengeluaran mahasiswa. Dari 83 sampel,mahasiswa perempuan merupakan responden dominan dalam penelitian ini karena mahasiswa perempuan lebih banyak menggunakan OVO dan Go-Pay dari pada mahasiswa laki-laki, data yang diperoleh dari penelitian ini yaitu:

Tabel 1. Data Rekapitulasi Jawaban Responden

\begin{tabular}{|c|c|c|c|c|c|}
\hline Var. & Obs & Mean & Std. Dev. & Min. & Max. \\
\hline $\mathbf{Y}$ & 83 & 14,086 & 0,4729857 & 12,42922 & 15,42495 \\
\hline $\mathbf{X}_{\mathbf{1}}$ & 83 & 1856627 & 1115270 & 100000 & 7500000 \\
\hline $\mathbf{X}_{\mathbf{2}}$ & 83 & 0,4081928 & 0,2150363 & 0 & 1 \\
\hline $\mathbf{X}_{\mathbf{3}}$ & 83 & 4,580779 & 0,6504026 & 3,401197 & 5,703783 \\
\hline
\end{tabular}

Sumber :data diolah, 2019.

Pada tabel 1 dimana data rekapitulasi jawaban responden menyatakan dari 83 sampel yang digunakan terdapat pendapatan terkecil dari mahasiswa Fakultas Ekonomi dan Bisnis Universitas Padjadjaran yaitu sebesar $\mathrm{Rp} 100.000$ sedangkan pendapatan terbesar yaitu sebesar $\mathrm{Rp}$ 7.500.000. Pendapatan dalam data ini merupakan pendapatan mahasiswa selama satu bulan dengan rata-rata pengeluaran (setelah dilogaritma) sebesar Rp 14.086 atau sebesar Rp 1.408.600. Sedangkan untuk kisaran cashback yang telah ditetapkan oleh OVO dan Go-Pay, mahasiswa FEB akan Menggunakan kisaran cashback terendah sebesar 
$0 \%$ dan yang tertinggi sebesar $100 \%$. Data penggunaan OVO dan Go-Pay merupakan data gabungan dari penggunaan OVO dan penggunaan Go-Pay dari responden selama satu hari. Adapun untuk melengkapi data dalam penelitian ini penggunaan OVO dan Go-Pay merupakan penggunaan selama satu bulan dengan mengasumsikan satu bulan terdiri dari 30 hari. Dengan responden sebanyak 83 orang, penggunaan OVO dan Go-Pay paling sedikit selama satu bulan yaitu 3 kali dan paling besar yaitu 5 kali (setelah data diubah ke logaritma).

\section{- Hasil Regresi}

a. Uji Heteroskedastisitas

Heteroskedastisitas merupakan pengujian yang termasuk kedalam analisis regresi asumsi klasik, masalah heteroskedastisitas akan mengakibatkan variabel dependennya menjadi bias. Apabila hal tersebut terjadi akan berdampak terhadap nilai $\mathrm{t}$ dan nilai $\mathrm{F}$ yang tidak bisa ditentukan. Dalam mengatasi masalah heteroskedastisitas bisa dengan menggunakan koreksi standard error atau robust dan bisa menggunakan Weighted Least Squares Estimation untuk menormalkan variable-variabel yang menyebabkan adanya heteroskedastisitas. Menurut Gujarati adanya heterokedastisitas berpengaruh terhadap analisis model regresi, salah satu cara supaya masalah heteroskedastisitas dapat teratasi yaitu dengan menambah sampel. Tetapi menurut Woodbridge masalah heteroskedastisitas tidak bermasalah terhadap model regresi.

Tabel 2. Hasil Uji Heteroskedastisitas

\begin{tabular}{|c|c|c|}
\hline Chi2 & Prob $>$ Chi2 & LM \\
\hline 9,79 & 0,0018 & 26,90 \\
\hline
\end{tabular}

Sumber : data diolah, 2019.

Berdasarkan tabel 2 perlu adanya uji hipotesis untuk menguji heteroskedastisitas. Maka uji hipotesis:

Ho : $\operatorname{var}\left(u_{i} \mid x_{1}, x_{2}, x_{3}\right)=\sigma^{2}$ (tidak terdapat masalah heteroskedastisitas atau error term bersifat homoskedastisitas)

Ha : $\operatorname{var}\left(u_{i} \mid x_{1}, x_{2}, x_{3}\right)=\sigma_{i}^{2}$ (terdapat masalah heteroskedastisitas atau errorterm tidak bersifat homoskedastisitas)

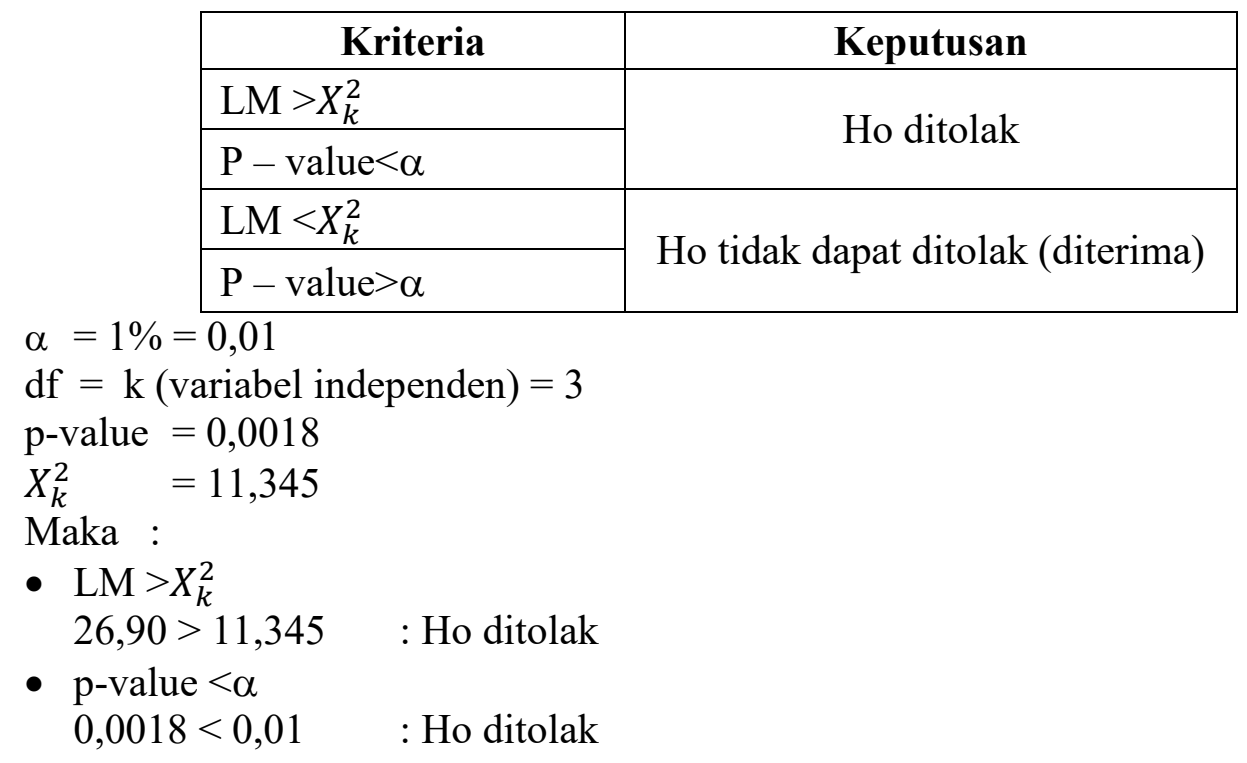




\section{EKONOMIKAWAN : Jurnal Ilmu Ekonomi dan Studi Pembangunan}

I55N : $1693-7600$ (Print), 155N : 2598-0157 (Online), hutp:/fumal.umstiac.id//ndex,php/ekawan

Dari uji tersebut $\mathrm{p}$-valuenya sebesar 0,0018 dengan $\alpha$ (tingkat signifikannya) sebesar $1 \%$ atau 0,01 maka $p$-value $<\alpha$ atau $0,0018<0,01$ berarti dalam model tersebut ada masalah heteroskedastisitas. Pengalisis dalam heteroskedastisitas bisa juga dengan melihat nilai LM dengan nilai $X_{k}^{2}$ (dalam tabel chi-square), apabila $\mathrm{LM}<X_{k}^{2}$ maka tidak terdapat masalah heteroskedastisitas atau error term bersifat homoskedastisitas. Dalam pengujian ini nilai LM yaitu sebesar 26,90 sedangkan nilai $X_{k}^{2}$ sebesar 11,345 maka $\mathrm{LM}>X_{k}^{2}$ atau 26,90 $>11,345$ sehingga Ho ditolak. Dapat disimpulkan dalam model regresi tersebut terdapat masalah adanya heteroskedastisitas atau error term tidak bersifat homoskedastisitas. Sehingga harus adanya koreksi untuk menangani masalah tersebut dengan koreksi standard error atau robust.

Tabel 3. Hasil Uji Regresi

\begin{tabular}{|c|c|c|c|c|c|c|}
\hline & & $\begin{array}{l}\text { Number of obs } \\
\mathrm{F}(3,79) \\
\text { Prob }>\mathrm{F} \\
\text { R-squared } \\
\text { Root MSE }\end{array}$ & $\begin{array}{ll}: & 83 \\
: & 20 \\
: & 0, \\
: & 0, \\
: & 0,\end{array}$ & $\begin{array}{l}3 \\
00 \\
26 \\
59\end{array}$ & & \\
\hline $\mathrm{Y}$ & Coef. & Std. Err. & $\mathrm{t}$ & $\mathrm{P}>|t|$ & \multicolumn{2}{|c|}{ [95\% Coef. Interval] } \\
\hline $\mathrm{X}_{1}$ & 0,000000303 & 0,0000000733 & 4,13 & 0,000 & $1,57 \mathrm{e}-07$ & $4,49 \mathrm{e}-07$ \\
\hline $\mathrm{X}_{2}$ & $-0,4102476$ & 0,1620954 & $-2,53$ & 0,013 & $-0,7328905$ & $-0,0876046$ \\
\hline $\mathrm{X}_{3}$ & 0,1428154 & 0,0495925 & 2,88 & 0,005 & 0,044104 & 0,2415267 \\
\hline Cons & 13,03733 & 0,2074539 & 62,84 & 0,000 & 12,62441 & 13,45026 \\
\hline
\end{tabular}

Sumber : data diolah, 2019.

$$
\widehat{Y}=13,03733+0,000000303 \widehat{X_{11}}-0,4102476 \widehat{X_{21}}+0,1428154 \widehat{X_{31}}
$$

Interpretasi:

1. $\beta_{1}=0,000000303$

"Setiap kenaikan variabel $\mathrm{X}_{1}$ sebesar 1 rupiah akan menyebabkan kenaikan variable $\mathrm{Y}$ sebesar $0,0000303 \%$, cateris paribus".

2. $\beta_{2}=-0,4102476$

"Setiap kenaikan variabel $\mathrm{X}_{2}$ sebesar $1 \%$ akan menyebabkan penurunan variable $\mathrm{Y}$ sebesar $41,02476 \%$, cateris paribus".

3. $\beta_{3}=0,1428154$

"Setiap kenaikan variabel $\mathrm{X}_{3}$ sebesar $1 \%$ akan menyebabkan kenaikan variable $\mathrm{Y}$ sebesar 14,28154, cateris paribus".

b. Uji Multikolineritas

Uji multikolinearitas merupakan pengujian untuk melihat apakah antara variabel independen terdapat kolinearitas atau hubungan dalam model regresi. Salah satu cara yang digunakan untuk menguji multikolinearitas yaitu dengan melihat Variance Inflation Factor (VIF) yang terdapat dalam model regresi. Apabila Variance Inflation Factor (VIF) kurang dari $10(\mathrm{VIF}<10)$ dan nilai Tolerance atau yang dikenal dengan 1/VIF lebih besar dari $0,1(1 / \mathrm{VIF}>0,1)$, maka model tersebut tidak terdapat gejala multikolinearitas. Apabila adanya masalah multikolinearitas akan menyebabkan hasilhasil estimasi tetap tidak bias dan varian serta standard error akan meningkat. 
I55N : $1693-7600$ (print), 155N : 2598-0157 (Online), hutp://fumal_umstiacid//index.php/ekawan

Tabel 4. Hasil Uji Multikolinearitas

\begin{tabular}{|c|c|c|}
\hline Variabel & VIF & 1/VIF \\
\hline $\mathrm{X}_{1}$ & 1,06 & 0,945339 \\
\hline $\mathrm{X}_{2}$ & 1,05 & 0,949395 \\
\hline $\mathrm{X}_{3}$ & 1,02 & 0,982679 \\
\hline Mean VIF & 1,04 & \\
\hline
\end{tabular}

Sumber : data diolah, 2019.

Dalam penelitian ini dapat dihasilkan bahwa:

Ho : tidak terdapat multikolinearitas

$\mathrm{Ha}$ : terdapat multikolinearitas

Maka:

\begin{tabular}{|c|c|}
\hline Kriteria & Keputusan \\
\hline Mean VIF $\geq 5$ & \multirow{2}{*}{ Ho ditolak } \\
\hline Mean VIF $\geq 10$ & \\
\hline Mean VIF $<10$ & \multirow{2}{*}{$\begin{array}{c}\text { Ho tidak dapat ditolak (Ho } \\
\text { diterima) }\end{array}$} \\
\hline $1 / \mathrm{VIF}>0,1$ & \\
\hline
\end{tabular}

Mean VIF $=1,04$

Mean VIF $<10$

\section{$1,04<10$ maka Ho diterima}

Supaya tidak terdapat masalah multikolinearitas nilai mean VIF $<10$. Dari hasil penelitian diketahui nilai mean VIF sebesar 1,04 maka mean VIF $<10$ atau 1,04 $<10$. Sehingga dapat disimpulkan dari hasil pengujian tidak terdapat masalah multikolinearitas atau bebas dari hubungan anatar variabel independen yang akan mempengaruhi terhadap variabel dependen.

\section{- Uji Model regresi}

Menurut Winarsun (2002) dalam (Hasanah, 2008) menyatakan bahwa analisis regresi merupakan teknik dalam statistik parameter untuk melihat adanya hubungan dan meramalkan variansi dari variabel $Y$ dan variabel $X$, serta sebagai penentu dari besaran dan arah koefisien dari variabel $\mathrm{Y}$ dan variabel $\mathrm{X}$. Dalam pengujian analisis regresi terdiri dari dua macam yaitu pengujian secara linear dan non-linear, untuk penelitian ini menggunakan uji linear dari data yang telah didapatkan dari hasil wawancara. Pengujian tersebut dilakukan dengan menguji:

\section{Uji Statistik $\mathbf{F}$}

Ho : $\beta_{1}=\beta_{2}=\beta_{3}=0$ (tidak terdapat pengaruh simultan antara variabel independen dengan variabel dependen)

Ha : minimal ada 1 nilai $\beta_{\mathrm{i}} \neq 0$ (minimal ada 1 variabel independen yang mempengaruhi variabel dependen)

\begin{tabular}{|c|c|}
\hline Kriteria & Keputusan \\
\hline F-stat $\leq$ F- tabel & Ho diterima \\
\hline F-stat $>$ F- tabel & Ho ditolak \\
\hline
\end{tabular}




$$
\begin{aligned}
\text { df1 } & =\mathrm{k}=3 \\
\mathrm{df} 2=\mathrm{n}-\mathrm{k}-1 & \\
= & 83-3-1 \\
= & 79 \\
& \text { F-stat }=\frac{R^{2} / k}{\left(1-R^{2}\right) /(n-k-1)} \\
& =\frac{0,5426 / 3}{(0,4574) /(83-3-1)} \\
& =31,23844921
\end{aligned}
$$

F-tabel $\quad: 2,6049$

$\alpha=1 \%=0,01$

F-stat $>$ F- tabel

$$
31,23844921>3,782 \quad: \text { Ho }
$$

ditolak

Dengan menggunakan tingkat signifikan 1\%, pengujian F-stat harus lebih besar dari F-tabel sehingga bisa menentukan adanya pengaruh dari variabel independen terhadap variabel dependennya. Dalam penelitian ini nilai dari F-stat lebih besar dari pada F-tabelnya dengan besaran F-stat 31,23844921 dan F-tabel 3,782, berarti F-stat > F-tabel atau 31,23844921 >3,782. Sehingga variabel independen dalam penelitian ini berupa variabel pendapatan, kisaran cashback yang digunakan, serta penggunaan dari OVO dan Go-Pay berpengaruh terhadap variabel dependennya yaitu pengeluaran mahasiswa.

\section{Uji Statistik t}

- $\beta_{1}\left(X_{1}\right)$

Ho : $\beta_{1}=0$ (tidak terdapat pengaruh yang signifikan antara variabel $\mathrm{X}_{1}$ dengan variabel $Y$ )

$\mathrm{Ha}: \beta_{1} \neq 0$ (terdapat pengaruh positif yang signifikan antara variabel $\mathrm{X}_{1}$ dengan variabel $Y$ )

\begin{tabular}{|c|c|}
\hline Kriteria & Keputusan \\
\hline $\mathrm{t}$-stat $\leq \mathrm{t}$ - tabel & Ho diterima \\
\hline t-stat $>$ t- tabel & Ho ditolak \\
\hline
\end{tabular}

$$
\begin{aligned}
\text { t-stat } & =\frac{\widehat{\beta_{n}}-\beta_{n}}{S E\left(\widehat{\beta_{n}}\right)} \\
& =\frac{0,00000303-0}{0,0000000733} \\
& =4,1336971351 \\
& \approx 4,13 \text { (dibulatkan) } \\
\text { df }=\mathrm{n}-\mathrm{k}-1 & \alpha=1 \%=0,01 \\
=83-3-1 & \\
=79 &
\end{aligned}
$$

t-tabel $: 2,576$

Maka:

t-stat $>$ t-tabel

$4,13>2,576 \quad$ : Ho ditolak 


\section{EKONOMIKAWAN : Jurnal Ilmu Ekonomi dan Studi Pembangunan}

I55N : $1693-7600$ (print), 155N : 2598-0157 (Online), hutp://fumal_umstiacid//index.php/ekawan

Dengan tingkat signifikan 1\%, diperoleh nilai dari t-stat yaitu 4,13 sedangkan untuk t-tabelnya yaitu 2,576. Sehingga nilai dari t-stat $>$ t-tabel atau 4,13 $>2,576$ dengan tingkat signifikannya yaitu $0,000<0,01$. Maka hal tersebut menunjukan bahwa pendapatan atau pemasukan dari mahasiswa mempengaruhi adanya perilaku konsumen. Hal tersebut juga sesuai dengan penelitian yang telah dilakukan oleh Indrianawati \& Soesatyo (2015) dengan adanya peningkatan pendapatan akan berpengaruh terhadap tingkat konsumsi mahsiswa Pascasarjana di Universitas Negri Surabaya.

- $\quad \boldsymbol{\beta}_{2}\left(\mathbf{X}_{2}\right)$

Ho $: \beta_{2}=0$ (tidak terdapat pengaruh yang signifikan antara variabel $\mathrm{X}_{2}$ dengan variabel $\mathrm{Y})$

Ha $: \beta_{2}<0$ (terdapat pengaruh negatif yang signifikan antara variabel $X_{2}$ dengan variabel $\mathrm{Y})$

\begin{tabular}{|c|c|}
\hline Kriteria & Keputusan \\
\hline $\mathrm{t}$-stat $\leq \mathrm{t}$ - tabel & Ho diterima \\
\hline t-stat $>\mathrm{t}$ - tabel & Ho ditolak \\
\hline
\end{tabular}

$$
\begin{aligned}
\text { t-stat } & =\frac{\widehat{\beta_{n}}-\beta_{n}}{S E\left(\widehat{\beta_{n}}\right)} \\
& =\frac{-0,4102476-0}{0,1620954} \\
& =-2,530902172 \\
& \approx-2,53 \text { (dibulatkan) }
\end{aligned}
$$

$$
\begin{aligned}
& \mathrm{df}=\mathrm{n}-\mathrm{k}-1 \quad \alpha=1 \%=0,01 \\
& \quad=83-3-1 \\
& =79
\end{aligned}
$$

t-tabel : 2,326

Maka:

$\mathrm{t}$-stat $<\mathrm{t}$-tabel

$-2,53<2,326$ : Ho ditolak

Dengan tingkat signifikan $1 \%$, diperoleh nilai t-stat yaitu $-2,53$ sedangkan untuk nilai t-tabelnya sebesar 2,326. Berarti nilai dari t-stat $<$ t-tabel atau $-2,53<2,326$ dengan tingkat signifikannya $0,013<0,01$. Maka kisaran cashback yang telah ditetapkan oleh OVO dan Go-Pay yang biasanya akan digunakan oleh mahasiswa berpengaruh terhadap perilaku konsumen, sehingga bisa diketahui bahwa besar kecilnya persenan cashback yang ditetapkan oleh OVO dan Go-Pay akan mempengaruhi konsumsi dari mahasiswa, semakin besar cashback yang ditetapkan oleh OVO dan Go-Pay maka akan membuat mahasiswa tertarik dan melakukan pembelian.

- $\boldsymbol{\beta}_{3}\left(\mathbf{X}_{3}\right)$

Ho : $\beta_{3}=0$ (tidak terdapat pengaruh yang signifikan antara variabel $X_{3}$ dengan variabel Y)

Ha $: \beta_{3} \neq 0$ (terdapat pengaruh positif yang signifikan antara variabel $\mathrm{X}_{3}$ dengan variabel Y)

\begin{tabular}{|c|c|}
\hline Kriteria & Keputusan \\
\hline $\mathrm{t}$-stat $\leq \mathrm{t}$ - tabel & Ho diterima \\
\hline $\mathrm{t}$-stat $>\mathrm{t}$ - tabel & Ho ditolak \\
\hline
\end{tabular}




$$
\begin{aligned}
\mathrm{t} \text {-stat } & =\frac{\widehat{\beta_{n}}-\beta_{n}}{S E\left(\widehat{\beta_{n}}\right)} \\
& =\frac{0,1428154-0}{0,0495925} \\
& =2,879778192 \\
& \approx 2,88 \text { (dibulatkan) }
\end{aligned}
$$

$$
\begin{aligned}
& \mathrm{df}=\mathrm{n}-\mathrm{k}-1 \quad \alpha=1 \%=0,01 \\
& =83-3-1 \\
& =79 \\
& \text { t-tabel : 2,576 } \\
& \text { Maka: } \\
& \text { t-stat }>\text { t-tabel } \\
& 2,88>2,576 \quad \text { : Ho ditolak }
\end{aligned}
$$

Dengan tingkan signifikan 1\%, diperoleh bahwa nilai t-stat yaitu 2,88 sedangkan nilai t-tabelnya yaitu 2,576. Berarti nilai t-stat $>t$ - tabel atau 2,88 $>2,576$ dengan tingkat signifikan $0,005<0,01$, maka ada pengaruh dari penggunaan OVO dan Go-Pay terhadap perilaku konsumen, seorang mahasiswa ketika mendapatkan promosi cashback akan lebih banyak menggunakan OVO dan Go-Pay dari pada sebelum adanya promosi cashback. Hal tersebut sesuai dengan penelitian yang telah dilakukan di Jaboretabek yang menyatakan bahwa seringnya penggunaan brand OVO karena adanya kemudahan dalam menggunakan aplikasi, banyaknya promosi-promosi yang diberikan, dan adanya tingkatan harga yang lebih murah dari pada dengan membayar secara tunai (Sari, n.d.). Sehingga perusahaan-perusahaan financial technology (fintech) harus bisa mengeluarkan inovasi-inovasi atau promosi-promosi yang menarik perhatian konsumen supaya tetap menggunakan aplikasi fintech tersebut. Karena dengan adanya promosi seperti cashback bisa menambah penggunaan OVO dan Go-Pay dari sebelum adanya penggunaan OVO dan Go-Pay.

\section{Uji Koefisien Determinasi $\left(\mathrm{R}^{2}\right)$}

\section{$\mathbf{R}^{2}=\mathbf{0 , 5 4 2 6}$}

Artinya variabel $\mathrm{X}_{1}, \mathrm{X}_{2}$, dan $\mathrm{X}_{3}$ menjelaskan variabel $\mathrm{Y}$ atau variabel independen tersebut bisa menjelaskan variabel dependennya sebesar 54,26\% (0,5426 x 100\%). Sedangkan sisanya yaitu $45,74 \%\left(1-R^{2} \times 100\right)$ dipengaruhi oleh variabel-variabel lain diluar persamaan regresi ini.

\section{SIMPULAN}

Penelitian ini menunjukan uang saku mahasiswa dan penggunaan OVO, Go-Pay berpengaruh positif dan signifikan terhadap pengeluaran mahasiswa Fakultas Ekonomi dan Bisnis Universitas Padjadjaran. Sedangkan cashback berpengaruh secara negatif dan signifikan terhadap pengeluaran mahasiswa Fakultas Ekonomi dan Bisnis Universitas Padjadjaran. Penelitian ini juga menemukan penggunaan OVO dan Go-Pay banyak digunakan karena mudah, efisien dan banyaknya promosi yang ditawarkan OVO dan Go-Pay.

\section{DAFTAR PUSTAKA}

Aditya, D. (2013). Data dan Metode Pengumpulan Data Penelitian.

Adriany, V. (2018). Pengaruh Ekuitas Merek, Kualitas Pelayanan dan Bauran Promosi 
Terhadap Keputusan Pembelian Ulang Jasa Go-Jek Melalui Kepuasan Pelanggan. 6(1), 63-82.

Alfarizi, R. A., Rachma, N., \& Hufron, M. (n.d.). Pengaruh Promosi Penjualan dan Atmosfer Toko Terhadap Pembelian Impulsif dengan Emosi Positif Sebagai Variabel Intervening pada Konsumen Superindo Tlogomas Malang. Riset ManajemenPRODI MANAJEMEN, 75-87.

Ansori, M. (2019). Perkembangan dan Dampak Financial Technology (FinTech) Terhadap Industri Keuangan Syariah di Jawa Tengah. Studi Keislaman, 5(1), 31-45.

Astuti, R. P. F. (2016). Pengaruh Status Sosial Ekonomi Orang Tua, Literasi Ekonomi dan Life Style Terhadap Perilaku Konsumsi Mahasiswa Jurusan Pendidikan Ekonomi IKIP PGRI Bojonegoro. Edutama, 3(2), 49-58.

Davis, F. D. (1989). Perceived Usefulness, Perceived Ease of Use , and User Acceptance of Information Technology. STOR, 13(3), 319-340. https://doi.org/10.2307/249008

Dianti, S. (2017). Pengaruh Harga, Pelayanan dan Promosi terhadap Keputusan Jasa Angkutan Gojek pada Mahasiswa Jurusan Pendidikan IPS UIN Syarif Hidayatullah Jakarta.

Fitra, R. R. (n.d.). Pengaruh Perceived Usefulness, Perceived Ease of Use, M-Payment Experience dan Perceived Enjoyment Terhadap Penerimaan Penggunaan Teknologi Pembayaran OVO pada Grab Dengan Metode Tam ( Studi pada pengguna aplikasi GRAB di Yogyakarta).

Gujarati, D. N. (2003). Basic Economterics.

Hanifah, N. (2016). Perbedaan Hasil Belajar Materi Elastisitas Melalui Model Pembelajaran Kooperatif Tipe Jigsaw dan Student Archievment Division (Stad) Siswa Kelas X Sma Negeri 5 Banda Aceh.67-73.

Hasanah, N. N. (2008). Pengujian Heteroskedastisitas pada Regresi Non Linear dengan Menggunakan Uji Glejser. 153-164.

Indrianawati, E., \& Soesatyo, Y. (2015). Pengaruh Tingkat Pendapatan dan Pengetahuan Ekonomi Terhadap Tingkat Konsumsi Mahasiswa Program Pascasarjana Universitas Negeri Surabaya. Ekonomi Pendidikan Dan Kewirausahaan, 3(1), 214-226.

Irawati, D. (2018). Fintech dan Perubahan Struktur Industri Keuangan di Indonesia. 14(2), 69-77.

Khairunissa, K., Suharyono, \& Yulianto, E. (2017). Pengaruh Bauran Promosi Keputusan Pembelian dan Kepuasan Pelanggan. Jurnal Administrasi Bisnis (JAB), 46(2), 37-45.

Lisma, N., \& Haryono, A. (2016). Analisis Perilaku Konsumsi Mahasiswa Ditinjau Dari Motif Bertransaksi ( Studi Kasus pada Mahasiswi S1 Pendidikan Ekonomi Fakultas Ekonomi Universitas Negeri Malang Angkatan Tahun 2012 ). 9, 41-50.

Maghfira. (2018). Faktor - Faktor yang Mempengaruhi Penggunaan Sistem Pembayaran Go-Pay (Studi Kasus : Mahasiswa di Yogyakarta).

Mankiw, N. G. (2009). Macroeconomics. In Worth Publishers.

Muiz, M., Rachma, N., \& Slamet, A. R. (n.d.). Pengaruh Sales Promotion dan Kualitas Pelayanan Terhadap Minat Pembelian Ulang di Mediasi Variabel Kepuasan Konsumen. Prodi Manajemen, 50-62.

Muzdalifa, I., Rahma, I. A., \& Novalia, B. G. (2018). Peran Fintech dalam Meningkatkan Keuangan Inklusif pada UMKM di Indonesia. Masharif Al-Syariah, 3(1).

Nasution, P. R. (2014). Teknik Sampling. 1-7.

Rahma, T. I. F. (2018). Persepsi Masyarakat Kota Medan Terhadap Penggunaan Financial Technology. AT-TAWASSUTH: Jurnal Ekonomi Syariah, 3(1), 184-203. Retrieved from http://jurnal.uinsu.ac.id/index.php/tawassuth/article/view/1704 
EKONOMIKAWAN : Jurnal Ilmu Ekonomi dan Studi Pembangunan

I55N : $1693-7600$ (Print), 155N : 2598-0157 (Online), hutp://fumal_umstiacid//index.php/ekawan

Sari, Y. S. (n.d.). Dampak Technology Fit Dengan Menggunakan Mobile Money Terhadap Kepuasan Pelanggan (Brand OVO).

Suharyati, \& Sofyan, P. (2018). Edukasi fintech bagi masyarakat desa bojong sempu bogor. 1(2), 1-10.

Wulan, V. R. (2017). Financial technology (fintech) a new transaction in future. Journal Electrical Engineering and Computer Sciences, 2(1), 177-182. 